\title{
PENGEMBANGAN KEMAMPUAN BERPIKIR KREATIF DAN PEMECAHAN MASALAH MATEMATIS MAHASISWA MELALUI METODE DISKUSI
}

\author{
La Moma \\ Fakultas Keguruan dan Ilmu Pendidikan Universitas Pattimura \\ email: lamoma96@yahoo.com
}

\begin{abstract}
Abstrak: Tujuan penelitian adalah untuk mengetahui seberapa besar kontribusi perkuliahan kajian matematika sekolah 1 dengan metode diskusi terhadap pengembangan kemampuan berpikir kreatif matematis dan kemampan pemecahan masalah mahasiswa pada level KAM (atas, sedang, rendah). Penelitian ini merupakan tipe penelitian kuasi eksperimen. Sampel pada penelitian ini terdiri 89 orang mahasiswa semester 1 tahun pada Program Studi Pendidikan Matematika yang mewakili mahasiswa level tinggi, sedang, dan rendah. Data diperoleh lewat tes, sedang analisis data dilakukan lewat uji t dan anava dua jalur. Hasil penelitian menunjukkan bahwa: (1) ada perbedaan pencapaian KBKM mahasiswa antara kelas eksperimen dan kelas kontrol; (2) ada perbedaan pencapaian KPMM mahasiswa antara kelas eksperimen dan kelas kontrol; (3) tidak terdapat interaksi antara pembelajaran dan KAM mahasiswa terhadap kemampuan berpikir kreatif matematis; dan (4) tidak ada interaksi antara pembelajaran dan KAM mahasiswa terhadap kemampuan pemecahan masalah matematis.
\end{abstract}

Kata Kunci: kemampuan berpikir kreatif, pemecahan masalah matematis, metode diskusi

\section{DEVELOPING MATHEMATICAL CREATIVE THINKING AND PROBLEM SOLVING ABILITY THROUGH DISCUSSION METHOD}

\begin{abstract}
This study is aimed at determining the contribution of generative learning model using discussion method to the development of creative thinking ability and mathematics problem solving at different levels (high, medium, low). This study is a quasi-experimental research involving 89 first semester mathematics students represesenting different levels. Data were collected through test and analyzed using $t$-test, and two-way ANOVA. The results of the study are: (1) the creative thinking ability of students in experiment class and that of students in controll class are different, (2) the KPMM of experiement class and that of control class are different, (3) learning and KAM level have no correlation with creative thinking ability, and (4) learning and KAM level have no correlation mathematics problem solving ability.
\end{abstract}

Keywords: Creative thinking ability, mathematics problem solving, discussion method

\section{PENDAHULUAN}

Proses pembelajaran diseluruh jenjang pendidikan perlu lebih menekankan pada kemampuan mendapatkan, memilih, dan mengelolah informasi atau pengetahuan dengan efektif dan efisien. Untuk mencapai tujuan di atas, orang-orang terdidik yang membangun bangsa ini di masa depan memunyai kemampuan seperti yang diperlukan sistem pendidikan yang berorientasi pada pemecahan masalah, kemampuan berpikir kritis, berpikir kreatif matematis, dan berpikir logis (Depdiknas, 2003). Selain kemampuan berpikir kritis, berpikir kreatif, berpikir sistematis, dan berpikir logis, sangat mungkin untuk memunculkan dalam pembelajaran matematika mengingat semua kemampuan tersebut merupakan bagian dari tujuan pembelajaran matematika, disekolah-sekolah Indonesia diarahkan pula pada pemenuhan kebutuhan masa kini dan masa datang. Pembelajaran matematika untuk pemenuhan masa kini adalah ditekankan pada pemahaman konsep-konsep yang diperlukan untuk menyelesaikan masalah matematika dan ilmu lainnya.

Sumarmo (2010: 14) mengemukakan bahwa pembelajaran matematika guru sebagai fasilitator, motivator, dan menejer belajar bagi siswanya. Tugas guru adalah memilih informasi, tugas, atau masalah baru yang berkaitan dengan kemampuan awal (kondisi tak seimbang) kemudian guru membantu siswa siswa agar melalui akomodasi 
dan asosiasi terjadi keseimbangan baru. Kegiatan guru memilih informasi (tugas) baru, menciptakan lingkungan, dan memotivasi mahasiswa secara keseluruhan menggambarkan peran guru sebagai manager belajar. Depdiknas (2003:6) mengemukakan bahwa pembelajaran matematika diperolehan ditunjukkan untuk: (1) melatih cara berpikir dan bernalar dalam menarik kesimpulan, misalnya melalui kegiatan penyelidikan, eksplorasi, eksperimen; (2) mengembangkan aktivitas kreatif yang melibatkan imajinasi, intuisi, dan penemuan dengan mengembangkan pemikiran divergen, orisionil, rasa ingin tahu, membuat prediksi dan dugaan, serta mencoba-coba; (3) mengembangkan kemampuan memecahkan masalah, dan (4) mengembangkan kemampuan, menyampaikan informasi dan mengkomunikasikan gagasan antara lain melalui pembicaraan lisan, catatan, grafik, peta, diagram dalam menjelaskan gagasan.

Di perguruan tinggi, pembelajaran matematika diartikan sebagai kegiatan yang terprogram dalam desain faciliting, expowering, dan enabling (FEE), untuk membuat mahasiswa belajar aktif, yang menekankan pada sumber belajar. Selain itu, pembelajran juga dipandang sebagai proses pengembangan kreativitas berpikir agar dapat: (a) meningkatkan kemampuan berpikr; (b) meningkatkan pengetahuan; dan (c) mengkonstruksi pengetahuan baru sebagai upaya meningkatkan dan pengembangan materi perkuliahan (Direktorat Pemimbinaan Akademik dan Kemahasiswaan, 2005b:11 dalam Hidayat, 2010:3). Khususnya di perguruan tinggi pada program studi pendidikan matematika mata kuliah Kajian Matematika Sekolah 1, pembelajaran matematika lebih ditekankan pada penjelasan dan paparan peran penting matematika dalam memahami, mendalami dan mengembangkan mata kuliah lebih lenjut.

Kemampuan mahasiswa yang kurang dan proses pembelajaran yang tidak berlangsung sebagaimana mestinya dapat mengakibatkan hasil belajar mahasiswa menjadi rendah karena prestasi yang dicapai siswa di sekolah. Clack dan Boy (Hidayat, 2010: 5) menemukanbahwa 70\% ditentukan oleh faktor internal (kemampuan individu) dan 30\% ditentukan oleh faktor eksternal (lingkungan belajar). Proses pembelajaran yang tidak dikelola dengan baik diduga kuat sebagai penyebab hasil belajar rendah karena tujuan pembelajaran kurang jelas, pendekatan, metode pembelajaran kurang menyenangkan dan tidak tepat serta penilaian atau evaluasi yang kurang baik mengakibatkan pembelajaran menjadi bias. Hal seperti itu digambarkan oleh Sumarmo (2002) dan Fahinu (2007) sebagai proses pembelajaran yang terlalu banyak menekankan pada aspek doing,tetapi kurang menekankan pada aspek thinking. Perkuliahan lebih banyak menekankan pada keterampilan manipulatif ataiu bagaimana mengerjakan sesuatu tetapi kurang yang berkaitan dengan mengapa demikian dan apa implikasinya, dengan kata lain proses pembelajaran hanya berupa hafalan saja, buka pemecahan masalah, bukan penalaran, bukan berpikir kritis, dan bukan berpikir kreatif, atau penalaran.

Untuk meyakinkan peneliti dari hasil tentang temuan-temuan di atas, dalam pengajar mahasiswa Kajian Matematika Sekolah 1, penelitian mencoba mengamati penyelesaian soal ujian yang soalnya menyangkut pemccahan masalah dan prediksi jawaban mahasiswa tentang berbagai kemungkinan penyelesaian dalam suatu masalah dan bagaimana cara berpikir mahasiswa dalam menyelesaikan soal tersebut.

Dalam pemecahan masalah mahasiswa masih banyak tidak mampu dalam memecahkan soal yang diberikan. Umumnya mereka cenderung mengikuti seperti apa yang dicontohkan oleh dosen, tidak mampu menyelesaikan soal dengan caranya sendiri dan tidak biasa. Dengan mempelajari pemecahan masalah di dalam matematika, para mahasiswa harus mendapatkan cara-cara berpikir, kebiasaan tekun, dan rasa ingin tahu, serta kepercayaan diri di dalam situasi-situasi tidak akrab yang akan mereka hadapi di luar ruang lingkup matematika. Di bidang sehari-hari dan dunia kerja, menjadi seorang pemecah masalah yang baik bisa membawa manfaat-manfaat besar.

Kemampuan berpikir kreatif merupakan kemampuan individu untuk mencari cara, strategi, ide atau gagasan baru bagaimana memperoleh penyelesaian terhadap suatu permasalahan yang dihadapi. Siswa harus memiliki kemampuan berpikir kritis, logis, kreatif, sistematis, komunikasi, serta kemampuan dalam bekerja sama secara efektif.

Berpikir kreatif adalah kemampuan berpikir yang berawal dari adanya kepekaan terhadap situasi yang sedang dihadapi, bahwa di dalam situasi itu terlihat atau teridentifikasi adanya masalah yang ingin atau harus diselesaikan. Cara berpikir seperti ini diperlukan dalam mempelajari matematika, karena matematika memiliki struktur dan keterkaitan yang kuat dan jelas antara 
konsep-konsepnya sehingga memungkinkan siswa terbiasa untuk menggunakan keterampilan di atas dalam mengembangkan keterampilan berpikir kreatif matematis pada saat siswa dalam pemecahan masalah. Salah satu metode pembelajaran yang diharapkan dapat mengembangkan kemampuan berpikir kreatif matematis mahasiswa adalah metode diskusi.

Metode diskusi merupakan suatu metode pembelajaran yang menghadapkan siswa/mahasiswa pada suatu permasalahan. Tujuan utama metode diskusi adalah untuk memecahkan suatu permasalahan, menjawab pertanyaan, menambah dan memahami pengetahuan siswa, serta membuat suatu keputusan. Dapat dikatakan bahwa faktor-faktor yang diperkirakan memengaruhi kemampuan berpikir kreatif semuanya bersifat akademik. Faktor nonakademik, seperti minat, sikap, dan motivasi mahasiswa diperkirakan berkontribusi dalam hasil belajar dan kemampuan berpikir kreatif matematis. Ruseffendi (Hidayat, 2010:15) mengemukakan bahawa sikap positif terhadap matematika berkorelasi posistif dengan prestasi belajar.

Tujuan penelitian ini adalah untuk mengetahui pencapaian kemampuan berpikir kreatif matematis mahasiswa dan kemampuan pemecahan masalah matematis yang memperoleh pembelajaran dengan metode diskusi dan mahasiswa yang memperoleh pembelajaran konvesional, serta mengetahui interaksi antara level KAM (atas, sedang, rendah) dan Pembelajaran terhadap KBKM, dan terhadap KPMM mahasiswa.

\section{METODE}

Penelitian ini merupakan kuasi eksperimen dengan disain penelitian kelompok kontrol prestes-postes. Dalam penelitian ini digunakan dua kelas sebagai kelas eksperimen dan kelas kontrol. Pada tahap awal penelitian ini adalah menetapkan subjek penelitian, yaitu sebagai kelas eksperimen dan satu untuk kelas kontrol. Perlakuan ini diberikan untuk dilihat pengaruhnya terhadap aspek yang diukur, yaitu kemampuan berpikir kreatif matematis dan kemampuan pemecahan masalah matematis mahasiswa. Desain penelitian yang digunakan dalam penelitian ini sebagai berikut (Ruseffendi, 2005:53).

\begin{tabular}{ccc}
$\mathrm{O}$ & $\mathrm{X}$ & $\mathrm{O}$ \\
\hline $\mathrm{O}$ & & $\mathrm{O}$
\end{tabular}

Dalam penelitian ini dilibatkan faktor faktor kemampuan awal matematika (KAM) mahasiswa (atas, tengah, bawah). Subjek penelitian ini adalah mahasiswa Program Studi Pendidikan Matematika yang mengambil mata kuliah Kajian Matematika Sekolah 1 yang berasal dari level KAM (atas, tengah, bawah) di salah satu perguruan tinggi negeri kota Ambon. Mahasiswa terdiri atas dua kelompok, yaitu kelompok eksperimen (pembelajaran dengan metode diskusi) dan kelompok kontrol (MPK) yang berjumlah 45 orang siswa kelompok eksperimen (MPG) dan 44 orang siswa dari kelompok kontrol (MPK) sehingga secara keseluruhan berjumlah 89 orang.

Instrumen yang digunakan untuk mengukur kemampuan berpkir kreatif matematis dan kemampuan pemecahan masalah matematis mahasiswa terdiri atas dua jenis tes, yaitu masingmasing terdiri dari 5 item tes bentuk uraian. Tes dilakukan dua kali, yaitu pretes dilaksanakan sebelum pembelajaran dan postes dilaksanakan setelah pembelajaran. Untuk menguji perbedaan tersebut digunakan uji t, ANOVA dua jalur, dan dilanjutkan dengan uji beda lanjut pasangan kelompok data (Post-Hoc) melalui GLM, namun sebelum dilakukan pengujian terlebih dahulu dilakukan uji prasyarat yaitu uji normalitas data dan homogenitas. Pada penelitian ini kedua syarat di atas terpenuhi, yaitu data normal dan homogen, dan keseluruhan perhitungan statistik menggunakan bantuan Program SPSS 17.0 for Windows.

\section{HASIL DAN PEMBAHASAN \\ Pencapaian Kemampuan Berpikir Kreatif Matematis berdasarkan Kelompok Pembe- lajaran}

Analisis data untuk mengetahui pencapaian kemampuan berpikir kreatif matematis mahasiswa akan dilakukan dengan memanfaatkan skor postes dari kelompok eksperimen (pembelajaran dengan metode diskusi) dan kelompok kontrol (MPK). Deskripsi data pencapaian kemampuan berpikir kreatif matematis berdasarkan kelompok pembelajaran dapat dirangkum dalam Tabel 1.

\section{Tabel 1. Data Pencapaian Kemampuan Ber- pikir Kreatif Matematis Berdasarkan Kelompok Pembelajaran}

\begin{tabular}{lccc}
\hline Pembelajaran & N & Rata-rata & $\begin{array}{c}\text { Simpangan } \\
\text { Baku }\end{array}$ \\
\hline Metode Diskusi & 45 & 74,711 & 6,804 \\
Konvension & 44 & 59,272 & 18,523 \\
\hline
\end{tabular}

Keterangan: Skor maksimal ideal $=75$ 
Berdasarkan hasil pada Tabel 1, dapat diketahui bahwa kualitas pencapaian kemampuan berpikir kreatif matematis mahasiswa yang memperoleh pembelajaran dengan metode diskusi lebih besar secara statistik dibandingkan dengan siswa yang memperoleh pembelajaran konvensional (MPK). Hal ini dilihat dari perolehan rata-rata skor postes mahasiswa dari kelompok pembelajaran dengan metode diskusi dan kelompok MPK.

Demikian pula penyebaran data skor postes (pencapaian) kemampuan berpikir kreatif matematis mahasiswa antara kelompok pembelajaran dengan metode diskusi lebih kecil dibandingkan dengan kelompok pembelajaran konvensional (MPK). Dengan katalain, model pembelajaran generatif memberikan manfaat bagi siswa dalam pencapaian kemampuan berpikir kreatif matematis.

Hasil uji $t$ untuk mengetahui perbedaan dua rata-rata pencapaian kemampuan berpikir kreatif matematis antara dua kelompok mahasiswa disajikan pada Tabel 2.

Berdasarkan hasil perhitungan pada Tabel 2 tersebut dapat disimpulkan bahwa ada perbedaan yang signifikan pencapaian kemampuan berpikir kreatif matematis antara mahasiswa yang menggunakan pembelajaran dengan metode diskusi dan pembelajaran konvensional.

Interaksi antara Pembelajaran dan Level KAM Terhadap Kemampuan Berpikir Kreatif Matematis

Interaksi antara pembelajaran PMD dan MPK dengan level KAM dalam kemampuan berpikir kreatif matematis mahasiswa diketahui dengan cara menganalisis data dari Level KAM pada pembelajaran dengan metode diskusi dan pembelajaran konvensional melalui uji anova dua jalur, ditunjukkanpada Tabel 3.

Berdasarkan hasil pada Tabel 3, tampak bahwa level KAM dan pembelajaran secara bersama-sama tidak memberikan pengaruh yang signifikan terhadap peningkatan kemampuan berpikir kreatif matematis mahasiswa. Secara grafis dapat dilihat pada Gambar 1.

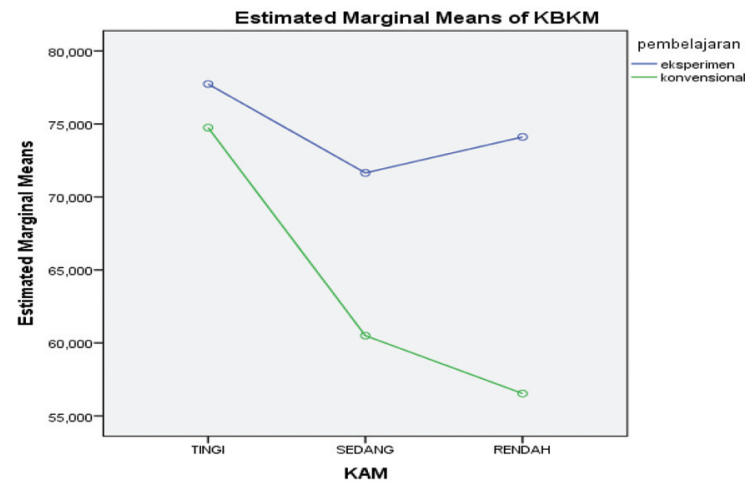

Gambar 1. Interaksi antara Pembelajaran dan Level KAM terhadap Kemampuan Berpikir Kreatif Matematis (KBKM)

\section{Pencapaian Kemampuan Pemecahan Masalah Matematis BerdasarkanKelompok Pembela- jaran}

Deskripsi data pencapaian kemampuan pemecahan masalah matematis mahasiswa berdasarkan kelompok pembelajaran meliputi ratarata skor, dan simpangan baku. Deskripsi data pencapaian kemampuan pemecahan masalah matematis berdasarkan kelompok pembelajaran dapat dirangkum dalam Tabel 4.

Tabel 2. Pencapaian Kemampuan Berpikir Kreatif Matematis Berdasarkan Kelompok Pembelajaran

\begin{tabular}{ll}
\hline \multirow{3}{*}{ Pembelajaran } & Kemampuan Pemecahan Masalah Matematis (KPMM) \\
\cline { 2 - 3 } & $\begin{array}{l}\text { Perbandingan Rata-rata } \\
\text { Postes }\end{array}$ \\
\hline
\end{tabular}

PMD dengan MPK 74,711 >59,9325,9510,000Tolak

$\mathrm{H}_{\mathrm{o}}$ : Tidak ada perbedaan pencapaian kemampuan berpikir kreatif matematis antara kedua kelompok pembelajaran (eksperimen dan kontrol)

Tabel 3. Pembelajaran dan Level KAM Terhadap Kemampuan Berpikir Kreatif Matematis (KBKM) Mahasiswa

\begin{tabular}{|c|c|c|c|c|c|}
\hline \multirow{2}{*}{$\begin{array}{l}\text { Sumber } \\
\text { Level KAM }\end{array}$} & Jumlah Kuadrat df & \multicolumn{2}{|c|}{ Rerata Kuadrat } & \multirow{2}{*}{$\frac{\text { F Sig. }}{0,044}$} & \multirow{2}{*}{$\frac{\mathbf{H}_{\mathbf{0}}}{\text { Ditolak }}$} \\
\hline & 1192,964 & 2596,482 & 3,243 & & \\
\hline Pembelajarar & 1699,544 & 16999,554 & 9,240 & 0,003 & Ditolak \\
\hline Level KAM & ajaran484,988 & 2242,494 & 1,318 & 0,273 & Diterima \\
\hline
\end{tabular}


Tabel 4. Data Pencapaian Kemampuan Pemecahan Masalah Matematis Berdasarkan Klompok Pembelajaran

\begin{tabular}{lccc}
\hline Pembelajaran & N & Rata-rata & SB \\
\hline Metode Diskusi & 45 & 74,909 & 6,751 \\
Konvensional & 44 & 59,682 & 18,054 \\
\hline
\end{tabular}

Keterangan: Skor maksimal ideal $=100$

Hasil uji data postes kemampuan pemecahan masalah matematis mahasiswa disajikan pada Tabel 5.

Dapat disimpulkan bahwa ada perbedaan yang signifikan pencapaian kemampuan pemecahan masalah matematis antara mahasiswa yang menggunakan pembelajaran dengan metode diskusi dan pembelajaran konvensional.

Interaksi antara Pembelajaran dan Level KAM Terhadap Kemampuan Pemecahan Masalah Matematis

Hasil analisis interaksi antara kelompok pembelajaran dengan KAM mahasiswa (tinggi, sedang, rendah) dalam kemampuan pemecahan masalah matematis mahasiswa disajikan pada Tabel 6.

Dapat disimpulkan bahwa KAM berpengaruh dalam kemampuan pemecahan masalah matematis mahasiswa. Secara grafis dapat dilihat pada Gambar 2 berikut.

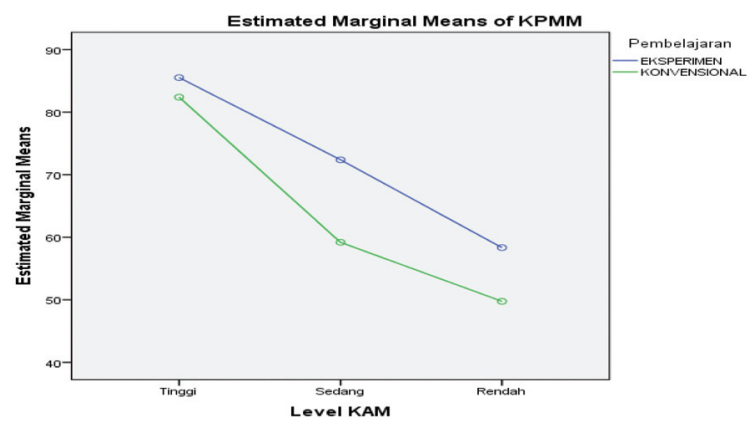

Gambar 2. Interaksi antara KAM dan Pembelajaran terhadap Kemampuan Pemecahan Masalah Matematis

\section{Pembahasan \\ Pencapaian Kemampuan Berpikir Kreatif Matematis}

Hasil penelitian menunjukkan bahwa terdapat perbedaan secara signifikan pencapaian kemampuan berpikir kreatif matematis antara siswa yang memperoleh pembelajaran dengan metode diskusi dan pembelajaran konvensional. Hal ini didasarkan pada rata-rata skor postes kemampuan berpikir kreatif matematis antara kelas eksperimen dan kelas kontrol yang memberikan nilai signifikan, sehingga memberikan dampak positif bagi siswa untuk mengembangkan kemampuan berpikir kreatif matematis.

Rata-rata skor pencapaian kemampuan berpikir kreatif matematis untuk kelas eksperimen atau kelas yang memperoleh pembelajaran dengan metode diskusi belum mencapai rata-rata skor ideal yang diharapkan yakni $75 \%$. Akan tetapi,

Tabel 5. Hasil Uji t Data Pencapaian Kemampuan Pemecahan Masalah Matematis Berdasarkan Kelompok Pembelajaran

\begin{tabular}{ll}
\hline \multirow{3}{*}{ Pembelajaran } & \begin{tabular}{l} 
Kemampuan Pemecahan Masalah Matematis (KPMM) \\
\cline { 2 - 3 } \\
Perbandingan Rata-rata
\end{tabular} \\
\hline PMD dengan MPK $74,909>59,6825,9840,000$ Ditolak \\
$\begin{array}{l}\mathrm{H}_{\mathrm{o}} \text { :Tidak ada perbedaan pencapaian Kemampuan Pemecahan Masalah Matematis antara kedua kelompok pembelajaran (eks- } \\
\text { perimen dan kontrol) }\end{array}$
\end{tabular}

Tabel 6. Hasil Uji ANOVA Dua Jalur antara Kelompok Pembelajaran dan KAM Mahasiswa terhadap Kemampuan Pemecahan Masalah Matematis

\begin{tabular}{lcccrc}
\hline Sumber data & Jumlah Kuadrat & df & Rerata kuadrat & FSig. \\
\hline Pembelajaran & 1111,561 & 1 & 1111,561 & 5,041 & 0,027 \\
\hline Level KAM & 9177,621 & 2 & 4588,810 & 20,812 & 0,000 \\
Pembelajaran * Level KAM & 248,123 & 2 & 124,061 & 0,563 & 0,572
\end{tabular}

Keterangan: $\mathrm{H}_{\mathrm{o}}$ : Tidak ada Interaksi antara Kelompok Pembelajaran dan KAM terhadap Kemampuan Pemecahan Masalah Matematis (KPMM) 
rata-rata skor pencapaian tergolong sedang, yaitu sebesar 74,711 dari skor ideal, sedangkan rata-rata skor pencapaian pada kelas kontrol atau siswa yang memperoleh pembelajaran konvensional tergolong sangat rendah, yaitu sebesar 59,932 dari skor ideal. Perbedaan kedua rata-rata tersebut setelah dilakukan uji secara statistik diperoleh bahwa terdapat perbedaan kemampuan berpikir kreatif matematis yang memperoleh pembelajaran dengan metode diskusi lebih baik daripada mahasiswa yang memperoleh pembelajaran konvensional. Dari hasil pengujian ini mengindikasikan bahwa penerapan pembelajaran konvesional kurang memberikan kontribusi terhadap pencapaian kemampuan berpikir kreatif siswa.

Setiawati (2014:184) menemukan bahwa kualitaskemampuan berpikir kreatif matematis siswa yang mengikuti PBM lebih baik daripada siswa yang mendapat pembelajaran biasa. Temuan Agung (2015:155) memperlihatkan bahwa peningkatan kemampuan berpikir kreatif matematis siswa yang belajar matematika melalui pendekatan Creative Problem Solving dibandingkan dengan siswa yang memperoleh pembelajaran biasa, lebih baik jika ditinjau secara keseluruhan. Hal yang sama juga ditemukan Mulyana dkk (2015:74), yaitu terdapat perbedaan kemampuan berpikir kreatif matematis siswa dengan inquiry learning dan discovery learning di SMP Negeri 57 Jakarta.

Berdasarkan beberapa temuan di atas, bila dikaitkan dengan hasil penelitian ini mendukung dan memperkuat temuan sebelumnya. Selain itu, temuan Haji (2011: 60) juga menunjukkan bahwa terdapat perbedaan kemampuan berpikir asli siswa SMP yang diajarkan dengan menggunakan pembelajaran generatif dengan pendekatan openended dengan pembelajaran biasa. Selain itu, pembelajaran dengan metode diskusi melibatkan aktivitas mental siswa berpikir. Mental berpikir seseorang yang telah melakukan pembelajaran akan berkembang sesuai dengan proses belajarnya. Aktivitas mental oleh Piaget menggunakan istilah "skema" yang diartikan sebagai pola tingkah laku yang dapat berulang kembali.

Suparno (2001: 21) mengatakan bahwa skema merupakan struktur mental seseorang dimana ia secara intektual beradaptasi dengan lingkungan sekitarnya. Dalam struktur kognitif setiap individu mesti ada keseimbangan antara asimilasi dengan akomodasi. Keseimbangan ini dimaksudkan agar supaya mendeteksi persamaan dan perbedaan yang terdapat pada stimulusstimulus yang dihadapi.

Dalam pembelajaran dengan metode diskusi, guru menciptakan situasi pembelajaran yang kondusif, dan menyenangkan membuat siswa lebih santai dalam memecahkan masalah. Dosen mempersiapkan tugas serta aktivitas dan mengantisipasi setiap respon yang mungkin dikemukakan oleh siswa. Siswa dituntut untuk lebih aktif dalam kegiatan pembelajaran, yakni siswa diberi kesempatan untuk mengemukakan gagasan-gagasan mereka mengenai topik yang dibahas. Dosen berperan memotivasi siswa dengan cara mengajukan pertanyaan yang sifatnya menggali pengetahuan yang ada dalam pikiran siswa, dan dosen juga menyiapkan di mana siswa diminta untuk membandingkan pendapatnya dengan pendapat siswa yang lain dan juga mengemukakan keunggulan dari pendapat mereka. Selain itu, guru meminta salah satu siswa perwakilan kelompok tampil di depan kelas mempresentasikan hasil pekerjaan kelompok, dan siswa dari kelompok lain memperhatikan dan memberikan pertanyaan atau saran cara penyelesaian lain yang lebih mudah dipahami.

\section{Interaksi antara Pembelajaran dan Level KAM terhadap Kemampuan Berpikir Kreatif Matematis}

Berdasarkan hasil analisis data ditemukan tidak terdapat interaksi antara pembelajaran dan level KAM. Hal ini berarti faktor pembelajaran dan level sekolah secara simultan (bersama-sama) tidak memberikan pengaruh yang signifikan terhadap kemampuan berpikir kreatif matematis mahasiswa. Temuan ini menunjukkan bahwa pembelajaran dengan metode diskusi cocok untuk diterapkan sebagai salah satu alternatif motode pembelajaran matematika di semua level KAM mahasiswa dalam pengembangan kemampuan berpikir kreatif matematis mahasiswa.

Selain itu, dari hasil analisis data ditemukan bahwa faktor level KAM mahasiswa dan pembelajaran tidak berpengaruh secara signifikan dalam peningkatan kemampuan berpikir kreatif matematis siswa, selanjutnya, bila dicermati lebih dalam ditemukan bahwa KAM seluruhnya memperoleh nilai tidak berbeda secara signifikan dalam peningkatan kemampuan berpikir kreatif. Hal ini sejalan dengan dari model pembelajaran dengan metode diskusi, yaitu pembelajaran yang berhubungan dengan pengetahuan awal siswa 
dengan pengetahuan baru yang dimiliki siswa. Hasil penelitian Setiawati (2010:185) menunjukkan bahwa tidak terdapat interaksi antara faktor pembelajaran yang digunakan dan faktor KAM siswa dalam peningkatan kemampuan berpikir kreatif matematis, sedangkan Abdullah (2012: 21) bahwa peningkatan kemampuan pemahaman matematis dan representasi siswa yang memperoleh pembelajaran kontekstual berbasis softskills lebih tinggi (Kategori sedang) daripada siswa yang memperoleh pembelajaran konvensional (kategori rendah), ditinjau secara keseluruhan. Penelitian Lambertus (2010:198) menunjukkan bahwa ada perbedaan peningkatan kemampuan berpikir kreatif matematis siswa yang pembelajarannya menggunakan pendekatan matematis realistik untuk siswa berkemampuan tinggi, sedang, dan rendah.

Perlu disadari, bahwa ada beberapa hal yang menyebabkan penerapan pembelajaran dengan metode diskusi ini mengalami kendala dalam upaya peningkatan kemampuan berpikir kreatif matematis siswa, yakni kurang kesiapan siswa dalam mengikuti pembelajaran, siswa sudah terbiasa dengan pembelajaran konvensional, siswa tidak mengikuti pelajaran dengan sungguh-sungguh, dan juga belum terbiasa dengan soal-soal non rutin dan open-ended dalam pembelajaran matematika.

\section{Pencapaian Kemampuan Pemecahan Masalah Matematis}

Hasil penelitian menunjukkan bahwa terdapat perbedaan secara signifikan pencapaian kemampuan pemecahan masalah matematis antara mahasiswa yang memperoleh pembelajaran dengan metode diskusi dan pembelajaran konvensional. Hal ini didasarkan pada rata-rata skor postes kemampuan pemecahan masalah matematis antara kelas eksperimen dan kelas kontrol yang memberikan nilai signifikan, sehingga memberikan dampak positif bagi siswa untuk mengembangkan kemampuan pemecahan masalah matematis.

Rata-rata skor pencapaian kemampuan pemecahan masalah matematis untuk kelas eksperimen atau kelas yang memperoleh pembelajaran dengan metode diskusi hampir mencapai rata-rata skor ideal yang diharapkan yakni 100 . Akan tetapi, rata-rata skor pencapaian KPMM mahasiswa tergolong sedang, yaitu sebesar 74,909 dari skor ideal, sedangkan rata-rata skor pencapaian pada kelas kontrol atau siswa yang memperoleh pembelajaran konvensional tergolong sangat rendah, yaitu sebesar 59,682 dari skor ideal. Perbedaan kedua rata-rata tersebut setelah dilakukan uji secara statistik diperoleh bahwa terdapat perbedaan kemampuan pemecahan masalah matematis yang memperoleh pembelajaran dengan metode diskusi lebih baik daripada siswa yang memperoleh pembelajaran konvensional. Dari hasil pengujian ini mengindikasikan bahwa penerapan pembelajaran dengan metode diskusi memberikan kontribusi terhadap pencapaian kemampuan pemecahan masalah mahasiswa dalam perkuliahan KMS-1.

Hidayat (2010:170) menemukan bahwa kemampuan pemecahan masalah matematis mahasiswa yang memperoleh pembelajaran dengan strategi REACT lebih baik dibandingkan dengan kemampuan pemecahan masalah mahasiswa yang memperoleh pembelajaran konvensional. Sutresna (2015:276)) menemukan bahwa terdapat perbedaan peningkatan hasil belajar motorik dasar maupun matematika dasar antara siswa yang diajar dengan pendekatan pembelajaran terpadu dengan siswa yang diajar dengan pendekatan konvensional. Demikian juga hasil penelitian Edriati dkk (2015:293) menunjukkan bahwa peningkatan kemampuan matematis mahasiswa yang mengkuti perkuliahan menggunakan model jigsaw disertai penilaian diskusi,dan perkulaiahan konvensional.

Selain itu, pembelajaran dengan metode diskusi melibatkan aktivitas mental siswa berpikir. Mental berpikir seseorang yang telah melakukan pembelajaran akan berkembang sesuai dengan proses belajarnya. Suparno (2001:21) mengemukakan bahwa skema adalah suatu struktur mental dimana ia secara intelektual beradaptasi dengan lingkungan sekitarnya. Dengan demikian, skema merupakan struktur mental dimana seseorang secara intektual beradaptasi dengan lingkungannya.

Dalam pembelajaran dengan metode diskusi, guru menciptakan situasi pembelajaran yang kondusif, dan menyenangkan membuat siswa lebih santai dalam memecahkan masalah.Guru/ dosen mempersiapkan tugas serta aktivitas dan mengantisipasi setiap respon yang mungkin dikemukakan oleh mahasiswa. Mahasiswa dituntut untuk lebih aktif dalam kegiatan pembelajaran, yakni mahasiswa diberi kesempatan untuk mengemukakan gagasan-gagasan mereka mengenai 
topik yang dibahas. Dosen berperan memotivasi mahasiswa dengan cara mengajukan pertanyaan yang sifatnya menggali pengetahuan yang ada dalam pikiran mahasiswa. Guru juga menyiapkan di mana siswa diminta untuk membandingkan pendapatnya dengan pendapat siswa yang lain dan juga mengemukakan keunggulan dari pendapat mereka. Selain itu, dosen meminta salah satu mahasiswa perwakilan ke-lompok tampil di depan kelas mempresentasikan hasil pekerjaan kelompok, dan mahasiswa dari kelompok lain memperhatikan dan memberikan pertanyaan atau saran cara penyelesaian lain yang lebih mudah dipahami.

Uraian di atas, sejalan dengan teori konstruktivisme yang lebih menekankan pada siswa belajar harus membangun sendiri pengetahuan dalam pikirannya. Guru berperan sebagai fasilitator, memberikan motivator, telah menjadi kenyataan dalam pembelajaran ini telah dilakukan.

\section{Interaksi Pembelajara dan KAM terhadap Kemampuan Pemecahan Masalah Matematis (KPMM)}

Berdasarkan hasil analisis data ditemukan tidak terdapat interaksi antara pembelajaran dan level KAM terhadap kemampun pemecahan masalah matematis. Hal ini berarti faktor pembelajaran dan level KAM secara simultan (bersama-sama) memberikan tidak memberi pengaruh yang signifikan terhadap kemampuan pemecahan masalah matematis siswa. Temuan ini menunjukkan bahwa pembelajaran dengan metode diskusi cocok untuk diterapkan sebagai salah satu alternatif model pembelajaran matematika di semua level KAM mahasiswa dalam upaya pengembangan kemampuan pemecahan masalah matematis mahasiswa.

Hasil temuan dalam penelitian ini memperkuat dan melengkapi hasil-hasil temuan sebelumnya. Misalnya, Karlimah (2010:56) dan Hidayat (2010:170) yang menemukan bahwa tidak terdapat interaksi antara pembelajaran dengan strategi ditinjau dari level KAM dalam kemampuan pemecahan masalah matematis mahasiswa, dengan demikian dapat dikatakan bahwa hasil penelitian ini relevan dengan temuan sebelumnya, yaitu model pembelajaran dan level KAM tidak memberikan pengaruh yang signifikan dalam upaya pengembangan kemampuan pemecahan masalah matematis mahasiswa.
Perlu disadari, bahwa ada beberapa hal yang menyebabkan penerapan pembelajaran dengan metode diskusi ini mengalami kendala dalam upaya pengembangan kemampuan pemecahan masalah matematis mahasiswa, yakni kurang kesiapan mahasiswa dalam mengikuti pembelajaran, mahasiswa sudah terbiasa dengan pembelajaran konvensional, siswa tidak mengikuti pelajaran dengan sungguh-sungguh, dan juga belum terbiasa dengan soal-soal non rutin dan open-ended dalam pembelajaran matematika.

Hasil temuan di atas terkait juga dengan, mahasiswa mengalami kesulitan dalam mengkonstruksi pengetahuan sendiri berdasarkan pengetahuan yang telah dimilikinya sebelumnya, selain itu, soal-soal yang terkait dengan tes kemampaun berpikir kreatif mahasiswa mengalami kesulitan karena mereka belum terbiasa dengan soal openended, dan juga mengalami kesulitan dalam mengembangkan gagasan untuk menyelesaikan masalah yang informasinya belum cukup.

\section{SIMPULAN}

Berdasarkan hasil penelitian dapat dibuat kesimpulan sebagai berikut. Pertama, pencapaian kemampuan berpikir kreatif matematis mahasiswa yang memperoleh pembelajaran dengan menggunakan metode diskusi lebih baik daripada siswa yang memperoleh pembelajaran konvensional. Kedua, tidak terdapat pengaruh interaksi antara pembelajaran dan level KAM (tinggi, sedang, rendah) terhadap kemampuan berpikir kreatif matematis mahasiswa. Ketiga, pencapaian kemampuan pemecahan masalah matematis mahasiswa yang memperoleh pembelajaran dengan menggunakan metode diskusi lebih baik daripada siswa yang memperoleh pembelajaran konvensional. Keempat, tidak terdapat pengaruh interaksi antara pembelajaran dan level KAM (tinggi, sedang, rendah) terhadap kemampuan pemecahan masalah matematis mahasiswa.

\section{UCAPAN TERIMA KASIH}

Ucapan terima kasih kepada semua pihak yang telah membantu pelaksanaan penelitian ini, terutama kepada dosen yang membina matakuliah KMS-1 pada Program Studi Pendidikan Matematika FKIP Unpatti Ambon sebagai sampel penelitian telah melayani dalam berbagai kebutuhan. 


\section{DAFTAR PUSTAKA}

Abdullah, I. 2012. "Peningkatan Kemampuan Pemahaman Matematis dan Representasi Matematis Siswa SMP melalui Pembelajaran Kontekstual Berbasis Soft skills". Ringkasan Disertasi. SPS UPI. Tidak Diterbitkan.

Agung. B. 2015. Peningkatan Kemampuan Pemecahan dan Masalah Berpikir Kreatif Matematis dan Habits of Mind Siswa SMA melalui Pendekatan Creative Problem Solving. Thesis. SPS UPI. Repositori.upi. edu/16848/, diunduh 21 November 2016.

Depdiknas. 2003a. Kurikulum 2004. Standar Kompetensi Mata Pelajaran Matematika Untuk SMP/MTs Pusat Kurikulum, Badan Penelitian dan Pengembangan. Depdiknas.

Edriati, Sofia. 2015. "Efektifitas Model Jigsaw Disertai Penilaian Diskusi untuk Meningkatkan Kemampuan Matematis Mahasiswa", dalam Jurnal Cakrawala Pendidikan. Jurnal Ilmiah Pendidikan.Vol. XXXIV (2).

Hidayat, R. 2010. Pembalajaran Kontekstual dengan Strategi React dalam Upaya Pengembangan Kemampuan Pemecahan Masalah, Berpikir Kritis, dan Berpikir Kreatif Matematis Mahasiswa Bidang Sains. Disertai Doktor SPS. UPI. Tidak diterbitkan.

Fahinu. 2007. Meningkatkan Kemampuan Berpikir Kritis dan Kemandirian Belajar Matematika pada Mahasiswa melalui Pembelajaran Generatif. Disertasi Doktor pada SPS. UPI Tidak diterbitkan.

Haji, S. 2011. "Mengembangkan Kemampuan Berpikir Asli melalui Pembelajaran Generatif dengan Pendekatan Open-Ended ". Journal Pasudan. Journal of Mathematics Education. Tahun I No (1). ISSN 20892055.

Karlimah. 2010. Pengembangan kemampuan Komunikasi dan Pemcahan Masalah Mahasiswa PGSD melalui Pembelajaran Berbsis Masalah. Ringkasan Disertasi. Doktor. SPS UPI. Tidak diterbitkan.
Lambertus. 2010. Peningkatan Kemampuan Berpikir Kreatif dan Pemecahan Msasalah Matematik Siswa Sdmelalui Pendekatan Matematika Realistik. Disertasi. Doktor Pada SPS. UPI. Tidak diterbitkan.

Mulyana, A. dkk. 2015. "Perbedaan Kemampuan Berpikir Kreatif Matematis Siswa dengan Inquiry Learning dan Discovery Learning di SMPN 57 Jakarta", Sigma Jurnal. The Journal of Education, Mathematics, Science, adn Technology. Vol. II (02). ISSN 1411-516.

Mulyana, T dan Sabandar, J. 2005. Upaya Meningkatkan Kemampuan Berpikir Kreatif Matematik Siswa SMA Jurusan IPA melalui Pembelajaran dengan Pendekatan Deduktif-Induktif. Makalah. Disampaikan pada Seminar Nasional. Bandung, 20 Agustus 2005 .

Ruseffefndi, E. H. 2005. Dasar-dasar Penelitian Pendidikan \& Bidang Non-Eksakta Lainnya. Bagi: Para Peneliti, Penulis Skripsi, Penulis Tesis, Penulis Disertasi, Dosen Metode Penelitian dan Mahasiswa. Bandung: Tarsito.

Sabandar, J. 2007. Berpikir Reflektif. Makalah. Prodi Pendidikan Matematika SPS. UPI. Makalah Seminar Nasonal matematika dan Pendidikan matematika diselenggarakan Jurusan PMIPA UPI Bandung berkerjasama dengan Ikatan Alumni Prodi Matematika Pascasarjana UGM dan IndoMs Wilayah Jabar, Banteng, dan DKI Jakarta.

Setiawati. E. 2014. Memngembangkan Kemampuan Berpikir Logis, Kreatif, dan Habits of Mind Matematis melalui Pembelajaran Berbasis Masalah. Thesis SPS UPI. Repository.upi.edu/6583/, diunduh 13 November 2016.

Sumarmo, U. 2002. Pembelajaran Matematika untuk Mendukung Pelaksanaan Kurikulum Berbasis Kompetensi. Makalah pada pelatihan Guru MTs Bandung.

Sumarmo, U. 2010. Berpikir dan Disposisi Matematik: Apa, Mengapa, dan Bagi- 
mana dikembangkan pada Peserta Didik. Makalah. Prodi. Pendidikan Matematika SPS UPI.

Sutresna, N. 2015. "Belajar Gerak dan Matematika Dasar Melalui Pendekatan Pembelajaran
Terpadu di Sekolah Dasar", dalam Jurnal CakrawalaPendidikan, Jurnal Ilmiah Pendidikan. XXX IV (2), hlm. 268-276.

Suparno, P. 2001. Teori Perkembangan Kognitif Jean Piaget. Yogayakarta: Kanisius. 